\title{
CONSUMERS' ADOPTION OF SOCIAL COMMERCE: A SYSTEMATIC LITERATURE REVIEW
}

\author{
Said ALTINIŞIK ${ }^{*}$ (D) Sevgi ÖZKAN YILDIRIM11D \\ ${ }^{1}$ Information Systems/Informatics Institute, Middle East Technical University, 06800 Ankara, Turkey \\ asaid@metu.edu.tr, sevgiozk@metu.edu.tr
}

Received: 30.10.2017, Accepted: 30.11.2017

*Corresponding author

doi: $10.22531 /$ muglajsci.358776

\section{Abstract}

Social commerce though it is a relatively novel concept, has been an attracted field by both practitioners and scholars. In search for exploring underlying motives for social commerce usage many theories proposed and various factors studied by academic circles. In this study we review the social commerce literature to grasp a picture of the literature in terms of the social commerce activities as research basis, theories and factors employed by the studies and the countries that the studies were conducted. Our findings and concluding comments would be useful for future studies especially for newcomer researchers in the social commerce discipline.

Keywords: Social Commerce, E-Commerce, Systematic Literature Review

\section{MÜŞTERILERIN SOSYAL TİCARET KULLANIMI: BİR SISTEMATIKK LİTERATÜR TARAMASI}

$\ddot{0} \mathbf{z}$

Sosyal ticaret, görece yeni bir kavram olmasına rağmen hem işletmeler hem de akademisyenler tarafindan ilgi çeken bir alan olmuştur. Müşterilerin sosyal ticaret kullanımının altında yatan temel güdüleri ortaya koymak adına birçok teoriler öne sürülmüş ve birçok faktörler çalışllmıştır. Bu çalıșmada araştırmaların temellendirildiği sosyal ticaret aktiviteleri, çalışmalarda kullanılan teoriler, faktörler ve çalışmaların yapıldığı ülkeler açısından literatürün bir resmini elde etmek amacıyla literatür taraması yapılmıştır. Çalışmadaki bulgularımızın ve nihai yorumlarımızın sonraki çalıșmalar için özellikle de sosyal ticaret alanını yeni araștıranlar için faydalı olacağını umuyoruz.

Anahtar Kelimeler: Sosyal ticaret, E-Ticaret, Sistematik Literatür Taraması

\section{Introduction}

Shopping in its traditional form has been a social activity in its nature. We may be informed about a certain product by our friends, we may go to shopping together with our relatives, we have a long lasting relationship with the seller and after the purchase we share our purchase experience within our community circles.

However, as a revolutionary type of shopping, e-commerce though it provided some convenience, it lacked this social nature especially in its early stages. Relationship with the website/vendor was automatic, impersonal and anonymous [1]. People felt themselves lonely in their purchasing activities, and this caused the customer to be curious about the trustworthiness of the vendor.

Social commerce (SC) appeared as a solution to this drawback of e-commerce. Web 2.0 tools and use of social media for commercial purchases facilitated the social input in all stages of purchasing mentioned above [2]. Ecommerce sites, like Amazon, included social applications, like recommendations, discussion groups, product and brand communities in their websites. As the social input increased, the divergence between the traditional shopping and e-commerce has lessened. Wang and Zhang (2011) pointed upon this convergence in their social commerce definition as "convergence between online and offline environment."

While majority of the paper defines the social commerce as a new form of e-commerce as mentioned above, another stream of papers defines SC as a paradigm change in the way business is done. The use of social media has transformed marketing strategies and the way firms and customers interact [4].

According to a study \%76 of people trust their friend's product recommendations while only $\% 15$ of people trust traditional advertisements.[5] Therefore marketing's new role should be finding brand advocates through social media rather than assigning an advertising agency. Another example for new strategies is that marketing should support the 'linking value' of their products/services -rather than their 'use value'- through which they can hold together customers as a tribe of enthusiast.[6] Many companies now create 'brand families' and organize activities to hold the group together and these practices are regarded among the most effective drivers of customer loyalty $[7,8]$.

Maintaining a strong relationship with customers through social media not only provides sales in return; customers' interaction among themselves also creates a collective intelligence, which generates valuable knowledge input for the company. [9] In that sense customers are not 'value takers' any more rather they are 'value co-creators' that 
their experiences and feedbacks are invaluable sources of knowledge for the company. [10] These are just a few examples for what the social commerce has brought about for both customers and firms and the relationship between them as well.

Social commerce as an academic field is a relatively novel discipline and there is still room for literature reviews to picture the current situation of the area and guide the future studies by pointing out major gaps in the literature. As a subsequent study to previous literature reviews on SC area, this study aims to provide more insights about the customers' adoption of SC, especially in terms of theoretical basis, countries, SC activities and studied factors and any relationship between them. In this study we will address following research questions:

i. What are the theories proposed to describe the adoption of SC?

ii. What are the activities of social commerce that the papers based their analysis on?

iii. What are the countries that the studies are conducted?

iv. Which factors are studied for explaining consumers' adoption of SC?

v. What are the outcome measures studied in the literature?

\section{Methodology}

In this systematic literature review we conducted an online database search by using the keywords: "social commerce", "social shopping", "collaborative commerce", and "collaborative shopping" and the search was within the titles and subject terms. We also applied following criteria in the query: published either on an academic journal or as conference proceedings, peer reviewed, English as the language, full-text availability. We did not limit the publishers for two reasons: In order to have a full picture of the literature and secondly since we conduct quality check manually we did not find it necessary. We obtained 120 papers out of this query.

Upon these 120 papers we omitted 80 of them that do not serve for our research agenda and not fit the quality requirements. Our exclusion criteria were: it should be an empirical study, complete study -not in-progress paper-, it should provide survey questions and explains the constructs adequately and it should be related with the customers' adoption of SC. From this manual check we ended up with 40 papers. Later we applied forward-backward check through the references and we reached 7 additional papers and this made our final sample of 47 papers that we based our analysis on.

\section{Findings}

In this section we will present our findings and comments for each of the research questions.

\subsection{Theoretical Basis of Studies}

Researches employed various theories to understand customers' adoption of social commerce. 12 papers did not explicitly specify any theory, while remaining 35 papers have utilized 27 varied theories. To have a better understanding, we categorized the theories into two; first the theories that explain the social impact in the customers' online context; secondly the 'base theories' that explain the context apart from the social impact; these theories shed light upon either the cognitive/psychological states of the users -e.g. T.R.A., T.P.B., S.O.R- or their technology use e.g. TAM- or their media use-e.g. U.G.T-. List of the theories is provided in the Table 1 below.

Table 1 List of Theories Employed in the Literature

\begin{tabular}{lc}
\hline Social Theories & Freqency \\
\hline Social support theory & 5 \\
Trust transfer theory & 5 \\
Social presence theory & 3 \\
Relationship quality theory & 2 \\
Commitment-trust theory & 2 \\
Social exchange theory & 2 \\
Other theories* & 9 \\
Total & 28 \\
\hline
\end{tabular}

\begin{tabular}{lc}
\hline 'Base Theories' & Frequency \\
\hline S-O-R Theory & 5 \\
TAM & 5 \\
Uses and Gratifications theory & 3 \\
Theory of Planned Behavior & 2 \\
Other theories** & 8 \\
Total & 23 \\
\hline
\end{tabular}

*Word of mouth communication, Observational Learning Theory, Trust theory, Social identity theory, Social capital theory, Para social interaction theory, Social network theory, Social comparison theory, Information signaling theory

**Dual-process theory, Expectation confirmation model, Communication privacy management theory, Latent State-trait theory, Motivation theory, Socio-technical theory, Task-technology fit theory, Theory of Reasoned Action

It is observed that in total 15 social theories were applied 28 times, whereas 12 'base theories' were chosen 23 times in the literature. Figures indicate that no single theory dominated others in the literature and this shows a heterogeneous picture of the literature in terms of theoretical formulations.

Three mostly used social theories are appeared to be social support theory, social presence theory and trust transfer theory. The choice of these theories indicates that researchers examined the social input present in SC environment and which was not offered in the e-commerce at its early stages. Social support theory and social presence theory suggest that social commerce facilitates and also make use of the feeling of being cared of and sense of presence of others within the online context $[11,12]$. Trust transfer theory on the other hand, states that trust can be transferred from the trusted community to the vendor in case of a purchasing activity [13].

\subsection{Social Commerce Activities as Research Basis}

It is necessary to identify and analyze social commerce activities as the research basis since there are various SC practices and they differ in their characteristics. Following a brand page through social media should be treated 
differently than purchasing from a social shopping site, though both of them are under the SC umbrella. Therefore, it is necessary to analyze them separately and draw a theoretical map that allocates theories to each of the activities individually.

We gathered social commerce activity information directly from the survey questions that generally appear at the appendixes of papers. For a few cases where the survey questions are not provided, we analyzed the data collection method parts to understand what they asked to respondents as the SC activity basis, provided that it is explicitly stated.

Table 2 Social Commerce Activities

\begin{tabular}{lllc}
\hline $\begin{array}{l}\text { SC } \\
\text { Activity }\end{array}$ & Freq. & \multicolumn{1}{c}{ Subgroups } & Freq. \\
& & SNS Commercial & 3 \\
Social & 17 & SNS Brand Pages & 2 \\
networking & $(36 \%)$ & SNS Commercial Links & 2 \\
sites & & SNS In General & 10 \\
\hline Social & 30 & Daily Deal Sites & 3 \\
commerce & $(64 \%)$ & Mobile Social & 1 \\
sites & & SC sites In General & 26 \\
\hline
\end{tabular}

Through our review we observed that SC activities varied in line with the diversity of SC definitions in the literature. $64 \%$ of papers (that is 30 ) based their analysis on social commerce sites. Among them, 3 papers [14,15,16] worked on Groupon type daily deal sites, while one [17] studied on mobile social commerce, and the remaining 26 papers studied on social commerce sites. Some examples of SC sites are douban.com, taobao.com, meilishuo.com from China and groupon.com, kaboodle.com from US. Majority of those social commerce sites are content specific websites, such as on games, books and restaurants etc.

On the other hand, $36 \%$ of papers (that is 17) asked their questions on social networking sites. Among them 5 paper asked questions without giving any SNS name, by using 'social networking sites' in their questionnaire. Within remaining 12; 6 paper explicitly stated Facebook, 3 papers on Sina Weibo -a popular SNS site in China- and other 3 mentioned Renren, WeChat and Plurk as social networking sites.

Papers studied on social networking sites mostly focused on: C2C selling groups, brand page following, virtual communities sharing commercial experiences and the effect of social media 'likes'. Majority of those papers examines information sharing behavior of people and the effect of one's online network on his/her purchasing behavior.

\subsection{Countries That the Studies Were Conducted}

It is stated that cultural characteristics play a significant role in social commerce adoption. [3], [18] Therefore analyzing current literature in terms of their cultural settings would be a significant contribution to the academic field. We gathered national information directly from 'data collection' parts of the studies where authors describe their sample of respondents.

In our review we observed that studies in East Asia heavily dominates the literature in terms of their multitude.
Approximately $\% 70$ of papers collected their data from East Asia countries.

Table 3: Countries

\begin{tabular}{lcc}
\hline Country & Freq. & Percent \\
\hline China & 14 & $29,8 \%$ \\
U.S. & 12 & $25,5 \%$ \\
Korea & 8 & $17,0 \%$ \\
Taiwan & 5 & $10,6 \%$ \\
U.K. & 2 & $4,3 \%$ \\
Cross cultural & 2 & $4,3 \%$ \\
Jordan & 1 & $2,1 \%$ \\
Malaysia & 1 & $2,1 \%$ \\
India & 1 & $2,1 \%$ \\
Not specified & 1 & $2,1 \%$ \\
\hline
\end{tabular}

It is clear in the literature that social commerce sites are more popular and as a business model they are more successful in East Asia than the rest of the world. It is evident even from the authors' description of their rationale for both studying SC and choosing a certain SC site; one can easily reach out the opinion that there is a salient excitement and enthusiasm for social commerce sites in East Asia.

Though there are two cross-cultural studies [18], [19] empirically demonstrate the effect of cultural differences on SC adoption, there is still need for explaining the success of SC websites in East Asia, especially in the form of qualitative study to be more exploratory in the search for the real causes.

\subsection{Factors Studied In the Literature}

Through our review we observed that along with the diversity of theoretical formulations studied factors also depict a rich and heterogeneous picture. There are 108 different factors studied in our sample of papers. To have more insights of them we categorize the factors into four groups; (1) website or company related factors, (2) Factors that are related with the social impact within the SC online context, (3) personal factors, which are related with human cognitions, motivations, psychology, preferences etc., (4) Ambient and situational factors that exist in the online context. Top ten factors in terms of their frequencies are given in the Table 4 below. Full list of factors -other than top ten- are given below the tables.

Table 4: List of Factors Studied in The Literature

\begin{tabular}{ll}
\hline Website / Company related factors & Freq. \\
\hline Perceived privacy & 5 \\
Service quality & 5 \\
Perceived security & 4 \\
Social commerce constructs & 3 \\
System quality & 3 \\
Reliability & 2 \\
Visual appeal & 2 \\
Attractiveness & 2 \\
Ease of navigation & 2 \\
Perceived ease of use & 2 \\
\hline
\end{tabular}


Table 5: (Continues)

\begin{tabular}{lc}
\hline Social Factors & Freq. \\
\hline Social Presence & 10 \\
Relationship Quality & 6 \\
Social Support & 6 \\
Perceived interactivity & 5 \\
Informational Support & 5 \\
Familiarity/similarity & 5 \\
Emotional Support & 3 \\
Social value & 3 \\
Subjective norm & 2 \\
Social Interaction & 2 \\
\hline & \\
\hline Personal Factors & Freq. \\
\hline Trust towards website & 12 \\
Perceived enjoyment & 10 \\
Perceived usefulness & 9 \\
Satisfaction & 4 \\
Trust towards members & 3 \\
Trust towards community & 3 \\
Trust towards firm & 3 \\
Community commitment & 3 \\
Information seeking & 3 \\
Privacy apathy & 2 \\
\hline & \\
\hline Ambient Factors & Freq. \\
\hline Information quality & 4 \\
Customer Purchase & 2 \\
Number of reviews & 2 \\
Information Value & 2 \\
Positive valence of WOM & 1 \\
Negative valence of WOM & 1 \\
WOM content & 1 \\
Textual information quality & 1 \\
Number of 'likes" & \\
Information Asymmetry & \\
\hline
\end{tabular}

Full list of Factors Other Than Top Ten:

Website/Company related factors: Perceived personalization, WOM Quality, Perceived source competency, Perceived fairness, Website reputation, Website size, Transaction safety, Economic Feasibility, Members' expertise, Word-of-Mouth Referrals, Vividness, Playfulness, Accessibility, Flexibility, Support for recommendation, Telepresence.

Social factors: Cool \& New trend, Perceived benevolence/ integrity, Social norms, Likeability, Trustworthiness of Users, Reciprocal Relationship, Perceived sociability, Perceived critical mass, Community driveness, Closeness, Para-social interaction, Perceived Helpfulness,

Personal Factors: Hedonic Value, Utilitarian value, Relaxing entertainment, Trust toward product recommendation, Website commitment, Firm commitment, Customer identification, Customer loyalty, Relational capital, Cognitive capital, Individual motivations, Selfcongruence, Perceived ownership, Expectation Confirmation, Popularity, Reputation, Enjoyment in Helping Others, Perceived behavioral control, Escape, Passing time, Price consciousness, Brand consciousness, Confused from over choice, Tendency to social comparison online, Self-discovery value, Informational value, Social motivations, Hedonic motivations, Economic motivations, Convenience motivation, Flow, Uncertainty, Anticipated extrinsic rewards.

Ambient Factors: Structural Capital, Price, Promotion, Product, Music tempo, Length of promotion, having a Facebook page.

Summary of the four categories of factors is provided in the Table 5 below. It is seen that much of the diversity in the factors is observed on the personal factors that 43 various factors utilized 88 times in the literature.

Table 6: Summary of Studied Factors

\begin{tabular}{lcc}
\hline & $\begin{array}{c}\text { Number } \\
\text { of }\end{array}$ & $\begin{array}{c}\text { Total } \\
\text { Frequency }\end{array}$ \\
\hline Personal Factors & 43 & 88 \\
Social Factors & 22 & 61 \\
Website/Company Related & 26 & 46 \\
Ambient Factors & 17 & 23 \\
\hline
\end{tabular}

\subsection{Outcome Measures}

Diversity in the social commerce activities reflected itself on the outcome measures that there are numerous types of outcome measures studied in the literature.

Table 7: Outcome Measures

\begin{tabular}{lc}
\hline Outcome Measures & Frequency \\
\hline Social commerce intention & 17 \\
Purchase intention & 15 \\
Purchase behavior & 6 \\
Impulsive buying intention & 3 \\
Social commerce behavior & 2 \\
Intention to co-creation & 2 \\
Brand loyalty & 2 \\
Impulsive buying behavior & 1 \\
Customer satisfaction & 1 \\
E-WOM intention & 1 \\
Group purchase intention & 1 \\
Purchase cost & 1 \\
Continuance intention & 1 \\
Relationship quality & 1 \\
\hline
\end{tabular}

If we analyze the outcome measures we can observe that there are four main groups of them. The first group is related with the purchasing behavior as the outcome measure. This group takes three different forms: 'usual purchasing', impulsive purchasing and group purchasing. 
This group has the highest frequency -27 times- in the literature.

Second group is social commerce participation as the outcome measure and this group also manifested in three forms: sharing purchase experiences or seeking product recommendations, involving in co-creation and spreading electronic word of mouth information. This group observed 22 times in the literature.

Third group takes the long term relationship with the customer as the outcome measure: these are brand loyalty and continuance intention, 3 papers in the literature are dedicated under this category. Last group, with only 2 papers in quantity, takes the service quality as the outcome measure; they are electronic service quality and relationship quality.

\section{Discussion and Conclusion}

This paper draws a picture of social commerce studies as an academic field and specifically analyzes papers that examine the consumers' adoption of social commerce. As a subsequent study to Friedrich's [20] review where he examined studied factors in social commerce adoption; within that particular field, this study shed light upon theoretical basis, social commerce activities, factors, countries and outcome measures employed in the papers. In other words this study applied Busalim and Hussins's [21] analysis particularly on consumer adoption research theme, whereas Busalim and Hussin studied on the social commerce theme in general.

On the other hand, this study is unique for examining both social commerce activities as the research basis, for which the data was obtained directly from the survey questions, and the countries that the surveys were collected.

We can conclude with some recommendations for future studies in the SC domain. We mentioned that there is a vagueness in the literature in terms of the relationship between theoretical formulations and the social commerce practices. Therefore, there should be further analysis on social commerce activities that their unique characteristics should be examined; from that on we could map the activities with the proposed SC theories on individual basis. Secondly, there should be more cross-cultural studies as well as country specific in-depth qualitative studies in order to understand the role of cultural characteristics on SC usage patterns. This would make it clear to understand why SC sites are more popular in certain countries and why some cultures are reluctant adopt it smoothly.

Lastly, outcome measures employed in the studies should also be mapped both with theories and SC activities to have a clearer picture of the literature in academic sense. For example, impulsive purchasing and group purchasing behaviors can be related with hedonic motivations whereas 'usual purchasing' can be ascribed more to economic motivations, therefore there should be individual theoretical formulations for each.

Like any other academic paper, this study also is not free from limitations. Firstly, our analysis required to examine full text of papers, therefore the papers whose full texts were not accessible for us are not included in our reviews. This may potentially endanger the picture we draw for the
SC field. Secondly we cannot claim that our analyses as any other review study are free from subjective interpretations.

\section{Acknowledgment}

This article was presented as an oral presentation at the IMISC2017.

\section{References}

[1] N. Hajli and J. Sims, "Social commerce: The transfer of power from sellers to buyers," Technol. Forecast. Soc. Change, vol. 94, pp. 350-358, 2015.

[2] A. A. Rad and M. Benyoucef, "A Model for Understanding Social Commerce," Inf. Syst. J., vol. 4, pp. 1-11, 2010.

[3] C. Wang and P. Zhang, "The Evolution of Social Commerce: The People, Management, Technology, and Information Dimensions," Commun. Assoc. Inf. Syst., vol. 31, no. November 2012, pp. 105-127, 2011.

[4] A. T. Stephen and O. Toubia, "Deriving Value from Social Commerce Networks," J. Mark. Res., vol. 47, no. 2, pp. 215-228, 2010.

[5] L. Salvatori and F. Marcantoni, "Social Commerce : A Literature Review," Sci. Inf. Conf. 2015, pp. 1-6, 2015.

[6] D. E. Williams, "Integrating the conceptual domains of social commerce: a meta-theoretical perspective,"

The International Review of Retail, Distribution and Consumer Research, vol. 3969, no. September 2015. Taylor \& Francis, pp. 1-50, 2014.

[7] S. Hudson, L. Huang, M. S. Roth, and T. J. Madden, "The influence of social media interactions on consumer-brand relationships: A three-country study of brand perceptions and marketing behaviors," Int. J. Res. Mark., 2016.

[8] C. M. Sashi, "Customer engagement, buyer-seller relationships, and social media," Manag. Decis., vol. 50, no. 2, pp. 253-272, 2012.

[9] Z. Huang and M. Benyoucef, "From e-commerce to social commerce: A close look at design features," Electron. Commer. Res. Appl., vol. 12, no. 4, pp. 246259, 2013.

[10] Y. Wang, S. H. Hsiao, Z. Yang, and N. Hajli, "The impact of sellers' social influence on the co-creation of innovation with customers and brand awareness in online communities," Ind. Mark. Manag., vol. 54, pp. 56-70, 2016.

[11] J. B. Kim, "The Mediating Role of Presence on Consumer Intention to Participate in a Social Commerce Site," J. Internet Commer., vol. 14, no. 4, pp. 425-454, 2015.

[12] T.-P. . Liang, Y.-T. . Ho, Y.-W. . Li, and E. . Turban, "What drives social commerce: The role of social support and relationship quality," Int. J. Electron. Commer., vol. 16, no. 2, pp. 69-90, 2011.

[13] J. Chen, X. L. Shen, and Z. J. Chen, "Understanding social commerce intention: A relational view," Proc. Annu. Hawaii Int. Conf. Syst. Sci., pp. 1793-1802, 2014.

[14] I. Lee, S. Yoo, M. J. Choi, and D. H. Shon, "Determinants of Social Shopping Performance in Small and Medium-Sized Social Merchants: Theories 
and Empirical Evidence," J. Small Bus. Manag., vol. 53, no. 3, pp. 735-747, 2015.

[15] J. Ju and J. Ahn, "The effect of social and ambient factors on impulse purchasing behavior in social commerce," J. Organ. Comput. Electron. Commer., vol. 26, no. 4, pp. 285-306, 2016.

[16] D. Shim and J. Altmann, "How Marginally Does Impulse Buying Intention Change in Social Commerce? Nonparametric Regression Approach," Glob. Media J., vol. 14, no. 27, pp. 1-13, 2016.

[17] J. J. Hew, V. H. Lee, K. B. Ooi, and B. Lin, "Mobile social commerce: The booster for brand loyalty?," Comput. Human Behav., vol. 59, pp. 142-154, 2016.

[18] C. See and P. Ng, "Examining The Cultural Difference In The Intention To Purchase In Social Commerce," in Proceedings of Pacific Asia Conference on Information Systems, 2012, pp. 1-11.

[19] C. L. Hsu, M. C. Chen, K. Kikuchi, and I. Machida, "Elucidating the determinants of purchase intention toward social shopping sites: A comparative study of Taiwan and Japan," Telemat. Informatics, 2016.

[20] T. Friedrich, "Analyzing the Factors that Influence Consumers ', Adoption of Social Commerce - A Literature Review," in Twenty-first Americas Conference on Information Systems, 2015, pp. 1-16.

[21] A. H. Busalim and A. R. C. Hussin, "Understanding social commerce: A systematic literature review and directions for further research," Int. J. Inf. Manage., vol. 36, no. 6, pp. 1075-1088, 2016.

[22] B. Lu, W. Fan, and M. Zhou, "Social presence, trust, and social commerce purchase intention: An empirical research," Comput. Human Behav., vol. 56, pp. 225237, 2016.

[23] Y. Wang and C. Yu, "Social interaction-based consumer decision-making model in social commerce: The role of word of mouth and observational learning," Int. J. Inf. Manage., 2015.

[24] J. Chen and X. L. Shen, "Consumers' decisions in social commerce context: An empirical investigation," Decis. Support Syst., vol. 79, pp. 55-64, 2015.

[25] R. E. Crossler, "Intention to Engage in Social Commerce: Uses and Gratifications Approach," Twent. Am. Conf. Inf. Syst., 2014.

[26] K. Lee and G. Garrison, "Effects of Collectivism on Actual S-Commerce Use and the Moderating Effect of Price Consciousness," J. Electron. Commer. Res., 2013.

[27] I. J. Hwang, B. G. Lee, and K. Y. Kim, "Information asymmetry, social networking site word of mouth, and mobility effects on social commerce in Korea.," Cyberpsychol. Behav. Soc. Netw., vol. 17, no. 2, pp. 117-124, 2013.

[28] L. Liu, C. M. K. Cheung, and M. K. O. Lee, “An empirical investigation of information sharing behavior on social commerce sites," Int. J. Inf. Manage., vol. 36, no. 5, pp. 686-699, 2016.

[29] S. Kim and H. Park, "Effects of various characteristics of social commerce (s-commerce) on consumers' trust and trust performance," Int. J. Inf. Manage., vol. 33, no. 2, pp. 318-332, 2013.
[30] L. Xiang, X. Zheng, M. K. O. Lee, and D. Zhao, "Exploring consumers' impulse buying behavior on social commerce platform: The role of parasocial interaction," Int. J. Inf. Manage., vol. 36, no. 3, pp. 333-347, 2016.

[31] J. R. Venable, J. Pries-Heje, D. Bunker, and N. L. Russo, "Sellers versus buyers: differences in user information sharing on social commerce sites," Inf. Technol. People, vol. 29, no. 2, pp. 444-770, 2016.

[32] S.-B. Kim, K.-A. Sun, and D.-Y. Kim, "The Influence of Consumer Value-Based Factors on AttitudeBehavioral Intention in Social Commerce: The Differences between High- and Low-Technology Experience Groups," J. Travel Tour. Mark., vol. 30, no. 1-2, pp. 108-125, 2013.

[33] T. Hu, P. Zhang, and H. Dai, "What and How Social Commerce: Developing an Integrative Formative Model," 2016 3rd Int. Conf. Inf. Sci. Control Eng., pp. 748-752, 2016.

[34] B. Lu, Q. Zeng, and W. Fan, "Examining macrosources of institution-based trust in social commerce marketplaces:an empirical study," Electron. Commer. Res. Appl., vol. 20, pp. 116-131, 2016.

[35] P. Lal, "Analyzing determinants influencing an individual's intention to use social commerce website," Futur. Bus. J., vol. 3, no. 1, pp. 70-85, 2017.

[36] K.-L. Hsiao, J. C.-C. Lin, X.-Y. Wang, H.-P. Lu, and $\mathrm{H}$. $\mathrm{Yu}$, "Antecedents and consequences of trust in online product recommendations: An empirical study in social shopping," Online Inf. Rev., vol. 34, no. 6, pp. 935-953, 2010.

[37] K. Yang, X. Li, H. J. Kim, and Y. H. Kim, "Social shopping website quality attributes increasing consumer participation, positive eWOM, and coshopping: The reciprocating role of participation," $J$. Retail. Consum. Serv., vol. 24, no. C, pp. 1-9, 2015.

[38] X. Hu, Q. Huang, X. Zhong, R. M. Davison, and D. Zhao, "The influence of peer characteristics and technical features of a social shopping website on a consumer's purchase intention," Int. J. Inf. Manage., vol. 36, no. 6, pp. 1218-1230, 2016.

[39] D.-H. Shin, "User experience in social commerce: in friends we trust," Behav. Inf. Technol., vol. 32, no. 1, pp. 52-67, 2013.

[40] J. Shen, "Social comparison, social presence, and enjoyment in the acceptance of social shopping websites," J. Electron. Commer. Res., vol. 13, pp. 198-212, 2012.

[41] Y. R. Kang and C. Park, "Acceptance factors of Social shopping," 2009 11th Int. Conf. Adv. Commun. Technol., vol. 3, pp. 2155-2159, 2009.

[42] C. M. K. Cheung, B. S. Xiao, and I. L. B. Liu, "Do actions speak louder than voices? the signaling role of social information cues in influencing consumer purchase decisions," Decis. Support Syst., vol. 65, no. C, pp. 50-58, 2014.

[43] H. Zhang, Y. Lu, S. Gupta, and L. Zhao, "What motivates customers to participate in social commerce? the impact of technological environments 
and virtual customer experiences," Inf. Manag., vol. 51, no. 8, pp. 1017-1030, 2014.

[44] M. N. Hajli, "The role of social support on relationship quality and social commerce," Technol. Forecast. Soc. Change, vol. 87, pp. 17-27, 2014.

[45] Y. Wang and M. N. Hajli, "Co-creation in branding through social commerce: The role of social support, relationship quality and privacy concerns," 20th Am. Conf. Inf. Syst. AMCIS 2014, 2014.

[46] J. V. Chen, B. C. Su, and A. E. Widjaja, "Facebook C2C social commerce: A study of online impulse buying," Decis. Support Syst., vol. 83, pp. 57-69, 2016.

[47] T. Wang, R. K.-J. Yeh, and D. C. Yen, "Influence of Customer Identification on Online Usage and Purchasing Behaviors in Social Commerce," Int. J. Hum. Comput. Interact., vol. 31, no. 11, pp. 805-814, 2015.

[48] W. S. Chow and S. Shi, "Understanding Consumer Trust in Social Commerce Websites," Pacific Asia Conf. Inf. Syst. 2014 Proc., pp. 1-19, 2014.

[49] S. Sharma and R. E. Crossler, "Disclosing too much? Situational factors affecting information disclosure in social commerce environment," Electron. Commer. Res. Appl., vol. 13, no. 5, pp. 305-319, 2014.

[50] Y. Sun, K. K. Wei, C. Fan, Y. Lu, and S. Gupta, "Does social climate matter? on friendship groups in social commerce," Electron. Commer. Res. Appl., vol. 18, pp. 37-47, 2016.

[51] Y. C. J. Wu, J. P. Shen, and C. L. Chang, "Electronic service quality of Facebook social commerce and collaborative learning," Comput. Human Behav., vol. 51, pp. 1395-1402, 2015.

[52] C. S. P. Ng, "Intention to purchase on social commerce websites across cultures: A cross-regional study," Inf. Manag., vol. 50, no. 8, pp. 609-620, 2013.

[53] L. Qin and S. Kong, "Perceived Helpfulness, Perceived Trustworthiness, and Their Impact upon Social Commerce Users' Intention to Seek Shopping Recommendations," J. Internet Commer., vol. 14, no. 4, pp. 492-508, 2015.

[54] N. Hajli, J. Sims, A. H. Zadeh, and M.-O. Richard, “A social commerce investigation of the role of trust in a social networking site on purchase intentions," J. Bus. Res., vol. 71, pp. 133-141, 2016.

[55] J.-Y. M. Kang, K. K. P. Johnson, and J. Wu, "Consumer style inventory and intent to social shop online for apparel using social networking sites," $J$. Fash. Mark. Manag., vol. 18, no. 3, pp. 301-320, 2014.

[56] M. Hajli, "Social Commerce Adoption Model," UK Acad. Inf. Syst. Conf. Proc. 2012, p. Paper 16, 2012.

[57] H. H. Alshibly, "Customer Perceived Value in Social Commerce: An Exploration of Its Antecedents and Consequences," J. Manag. Res., vol. 7, no. 1, p. 17, 2014. 